Jurnal Sain Veteriner, Vol. 37. No. 1. Juni 2019, Hal. 128-133

DOI : $10.22146 /$ jsv.36704

ISSN 0126-0421 (Print), ISSN 2407-3733 (Online)

Tersedia online di https://jurnal.ugm.ac.id/jsv

\title{
Mycotoxin Binders Effect on Ovaries of Pregnant Mice Exposed to Zearalenone
}

\section{Efek Mycotoxin Binders pada Ovarium Mencit Bunting yang Terpapar Zearalenon}

\author{
Ragil Angga Prastiya ${ }^{1 *}$, Abdul Samik ${ }^{1}$, Amung Logam Saputro ${ }^{2}$
}

\author{
${ }^{1}$ Department of Veterinary Reproduction, Faculty of Veterinary Medicine, Universitas Airlangga \\ ${ }^{2}$ Faculty of Veterinary Medicine, Universitas Airlangga, Banyuwangi Campus, \\ Campus C Mulyorejo, Surabaya, Indonesia \\ *Email: ragilap@fkh.unair.ac.id
}

Naskah diterima : 4 Juli 2018, direvisi : 25 Maret 2018, disetujui : 25 April 2019

\begin{abstract}
Abstrak
Mikotoksin, metabolit sekunder yang dihasilkan oleh jamur, telah terbukti menimbulkan efek sitotoksik yang beragam pada hewan. Zearalenon adalah salah satu jenis mikotoksin yang dihasilkan oleh jamur Fusarium graminearum dan dapat mempunyai efek sitotoksik terhadap sistem reproduksi dan produktifitas ternak dengan menginduksi apoptosis pada organ ovarium, uterus dan plasenta. Penelitian ini menguji potensi mycotoxin binders untuk mengeliminasi efek dari zearalenon yang dilihat dari ekspresi caspase 3, kadar malondialdehyde (MDA), dan jumlah korpus luteum organ ovarium mencit (Mus musculus) bunting. Dua puluh mencit digunakan dalam penelitian ini yang dibagi menjadi 5 perlakuan yaitu $\mathrm{K}+$ (tidak dipapar zearalenon dan mycotoxin binders), $\mathrm{K}$ - (dosis zearalenon 0,1 mg/ekor/hari), P1 (dosis zearalenon $0,1 \mathrm{mg} /$ ekor/hari dan mycotoxin binders $0,5 \mathrm{mg} / \mathrm{ekor} / \mathrm{hari}$ ), P2 (dosis zearalenon 0,1 mg/ekor/hari dan mycotoxin binders $1 \mathrm{mg} / \mathrm{ekor} /$ hari), dan P3 (dosis zearalenon 0,1 mg/ekor/hari dan mycotoxin binders $2 \mathrm{mg}$ /ekor/hari), pemberian perlakuan dilakukan selama 10 hari. Hasil penelitian ini menunjukkan bahwa potensi mycotoxin binders berpengaruh pada ekspresi caspase 3 dimana pada P1, P2 ,P3 ekspresi caspase 3 menurun secara bertahap jika dibandingkan dengan K- (kontrol negatif). Hasil yang sama juga ditunjukkan pada kadar malondialdehyde (MDA) dimana K- mempunyai perbedaan yang nyata terhadap K+, P1, P2, and P3. Jumlah korpus luteum pada $\mathrm{K}$ - mempunyai perbedaan yang nyata dibandingkan $\mathrm{K}+, \mathrm{P} 1, \mathrm{P} 2$, dan $\mathrm{P} 3$. Kesimpulan penelitian ini, mycotoxin binders sangat efektif untuk mengeliminasi paparan zearalenon.
\end{abstract}

Kata kunci: Caspase 3; Korpus Luteum; Mycotoxin binders; Malondialdehyde (MDA); Zearalenon

\begin{abstract}
Mycotoxin, a secondary metabolite produced by mushroom, has proven to cause various cytotoxic effects to animals. Zearalenone is one type of mycotoxin which is produced by Fusarium graminearum mushroom and has a cytotoxic effect to the reproduction system and cattle productivity by inducing apoptosis in the animal's ovaries, uterus, and placenta. This research tested the potentials of mycotoxin binders in eliminating the effect of zearalenone which can be seen from the expression of caspase 3, the content of malondialdehyde (MDA), and the quantity of corpus luteum in the ovaries of pregnant mice (Mus musculus). Twenty mice were grouped into five different treatments, namely $\mathrm{K}+$ (not exposed to zearalenone and mycotoxin binders), $\mathrm{K}-(0.1 \mathrm{mg} / \mathrm{mouse} /$ day of zearalenone dosage), $\mathrm{P} 1$ $(0.1 \mathrm{mg} / \mathrm{mouse} /$ day of zearalenone dosage and $0.5 \mathrm{mg} / \mathrm{mouse} /$ day of mycotoxin binder dosage $), \mathrm{P} 2(0.1 \mathrm{mg} / \mathrm{mouse} /$ day of zearalenone dosage and $1 \mathrm{mg} /$ mouse/day of mycotoxin binders), and P3 (0.1 mg/mouse/day of zearalenone and 2 $\mathrm{mg} /$ mouse/day of mycotoxin binders), with 10-days treatment time. The results showed that the potentials of mycotoxin binders could be found on the gradual decline in the expression of caspase 3 in P1, P2 and P3 compared to that in $\mathrm{K}$ - (negative control). The results also showed a significant difference in the content of malondialdehyde (MDA) in K- compared to that in K+, P1, P2, and P3. Meanwhile, the quantity of corpus luteum in K- was also starkly different to that in $\mathrm{K}+, \mathrm{P} 1, \mathrm{P} 2$, and $\mathrm{P} 3$. It can then be concluded that mycotoxin binders are very effective in eliminating the exposure of zearalenone.
\end{abstract}

Keywords: Caspase 3; Korpus Luteum; Mycotoxin binders; Malondialdehyde (MDA); Zearalenon 
Ragil Angga et. al.

\section{Introduction}

Mycotoxin is a secondary metabolite which is produced by mushrooms and has proven to cause various toxic effects to animals and is also suspected to cause some diseases on humans (Bouaziz et al., 2008). Zearalenone is a non-steroidal mycotoxin which is synthesized through a polypeptide track by various Fusarium mushrooms. Zearalenone has a negative effect on reproduction system by causing structural changes in the uterus, ovaries, and placentas of the affected animals (Abbes et al., 2006).

The toxicity of zearalenone (ZEN) can trigger the apoptosis line of the dependent mitochondria (intrinsic line). These mitochondrial changes include: bax addition inside the outer membrane of the mitochondrion, loss of transmembrane potentials of the mitochondrion, PTPC opening, and cytochrome $\mathrm{c}$ release (Schollenberger et al., 2007). Exposure to zearalenone causes a sharp increase in the level of reactive oxygen species (ROS) in the early stage, even before the occurrence of changes and obstruction into intracellular homeostatic. ROS production occurred as a consequence of damage in the mitochondria (Bouaziz et al., 2008). Zearalenone can also cause a decrease in the ability of corpus luteum to produce progesterone hormone, so exposure to zearalenone in the early stage of animal pregnancy can affect pregnancy and may lead to miscarriage. Zearalenone intrauterine exposure in mice can affect the integrity of the oocyte, decrease the oocyte's ovulation level, and reduce the formation of corpus luteum (Awoniyi, et al., 1998).

Mycotoxin binders contain aluminosilicate's active carbon, cellulose, polisacarides, peptidoglycan, and synthetic polymers such as cholestryamine, polivinilpirolidon and its derivatives which are useful for binding the mycotoxin to reduce the effects of zearalenone (Avantaggiato et al., 2005). This research was aimed to investigate he effects of mycotoxin binders against the expression of caspase 3 , the level of malondialdehyde (MDA), and the quantity of corpus luteum in the ovaries of pregnant mice (Mus musculus) exposed to zearalenone.

\section{Materials and Methods}

The treatment of the test animals, the action of exposing zearalenone and mycotoxin binders, and the animal surgeries were conducted at the test animal compound, Faculty of Veterinary Medicine, Universitas Airlangga (Airlangga University). The tests of caspase 3 expressions with immunohistochemical tests and quantity test of corpus luteum were conducted at the Pathology Laboratory, Faculty of Veterinary Medicine, Universitas Airlangga. Meanwhile, the MDA level test was conducted at the Biochemical Laboratory of the Faculty of Medicine, Universitas Airlangga.

The test animals were 20 healthy house mice (Mus musculus) aged 12 weeks, weighing 25-40 grams that had never been used as test animals prior to this research.

The materials comprised Zearalenone ${ }^{\circledR}$ produced by Tocris Bioscience, USA, mycotoxin binders, sterile aquadest as solvents, feed, drinking water, husk as the flooring for each mouse cage, materials for the coloring making of immunohistochemistry, histology slides, and the materials for testing the malondialdehyde (MDA) levels.

The instruments include the test cages equipped with feed and drinking containers, digital scales, feeding tubes, surgical equipment, MDA test instrument, the instruments for making histology slides and immunohistochemisty, cameras, and an Olympus ${ }^{\circledR}$ CX-41 microscope for the observation.

\section{Experiments (Research Treatments)}

Twenty healthy female house mice (Mus musculus) aged 12 weeks, with an average weight of 40 
grams and ever been used in prior experiments, were divided into 5 treatment groups with four repetitions in each treatment.

The zearalenone dosage was based on Gajecka's (2012) and the dosage conversion table adopts Laurence dan Bacharach's (1993). The treatment of the mice was conducted orally with feeding tubes for 10 days after pregnancy occurred. The details of the dosage giving are as follows:

\begin{tabular}{ll}
\hline $\mathrm{K}+$ & no exposure with zearalenone and mycotoxin binders \\
\hline $\mathrm{K}-$ & $0.1 \mathrm{mg} /$ mouse/day of zearalenone dosage \\
$\mathrm{P} 1$ & $0.1 \mathrm{mg} /$ mouse/day of zearalenone dosage and $0.5 \mathrm{mg} / \mathrm{mouse} /$ day of mycotoxin binders \\
$\mathrm{P} 2$ & $0.1 \mathrm{mg} /$ mouse/day of zearalenone dosage and $1 \mathrm{mg} / \mathrm{mouse} /$ day of mycotoxin binders \\
$\mathrm{P} 3$ & $0.1 \mathrm{mg} / \mathrm{mouse} /$ day of zearalenone dosage and $2 \mathrm{mg} / \mathrm{mouse} /$ day of mycotoxin binders \\
\hline
\end{tabular}

After 10-day treatments, the female and male mice were coupled in a personal mating manner, and were observed for 5 days until copulations took place.

On the sixth day after the personal mating, the female mice were anesthetized with chloroform, and were fixated and dissected to split the left and right ovaria. The ovaria were then given the immunohistochemical coloring, tested for the MDA level, and given histology coloring to identify the corpus luteum.

\section{Techniques of Data Collection}

Observations of the expression of caspase 3 were conducted microscopically with a scoring method proposed by Sinuhaji (2013) as the following:

\begin{tabular}{lll}
\hline Score 0 & normal intensity & $0 \%$ field of view \\
Score 1 & low intensity & $0-25 \%$ field of view \\
Score 2 & medium intensity & $25-50 \%$ field of view \\
Score 3 & normal intensity & $>50 \%$ field of view \\
\hline
\end{tabular}

The scoring was conducted for five fields of view with a magnification to 400 times. The average score achieved from the five fields of view was then analyzed statistically.

Observation of the corpus luteum was conducted microscopically with a quantitative method by observing five slides in one field of view. The observation used a magnification to 100 times. The reading on the MDA level was conducted on all treatments by using TBA reactants to form MDA-TBA bonding. Statistical analysis was then conducted on the results of the laboratory test of MDA level and corpus luteum observations.

\section{Statistical Analysis}

The average scores of the caspase 3 expressions, MDA levels, and corpus luteum quantities were then tested for their normality with the Kolmogorov-Smirnov test. The parametric analyses were using one way ANOVA, and when a significance $(p<0.05)$ was reached, it will further continued with the Duncan's test.

\section{Results and Disccuss}

The means and the standard deviations of the scores of the caspase 3 expressions, malondialdehyde (MDA) levels, dan corpus luteum quantities were presented in Table 1.

The statistical tests on the expressions of caspase 3 showed that $\mathrm{K}$ - was significantly different $(\mathrm{p}<0.05)$ from $\mathrm{K}+, \mathrm{P} 1, \mathrm{P} 2$ and $\mathrm{P} 3 . \mathrm{K}+$ was significantly different $(\mathrm{p}<0.05)$ from $\mathrm{K}-, \mathrm{P} 1, \mathrm{P} 2$, and P3. P2 and P3 showed no significant difference $(\mathrm{p}>0.05)$. This research showed the numbers of cells that expressed 
Ragil Angga et. al.

caspase 3 with an average score of 6.20 in the zearalenone exposure without mycotoxin binders (K-). The numbers of cells that expressed caspase 3 gradually decreased: 4.55; 2.45; and 1.65 in $\mathrm{P} 1, \mathrm{P} 2$, and $\mathrm{P} 3$ respectively, while in positive control $(\mathrm{K}+)$ the average score of caspase 3 expressions was 0.75 .

Caspase 3 expressions of the granulose cells in the ovaries of the mice (Mus musculus) after the observation with a Olympus ${ }^{\circledR}$ CX-41 microscope is shown in Figure 1.

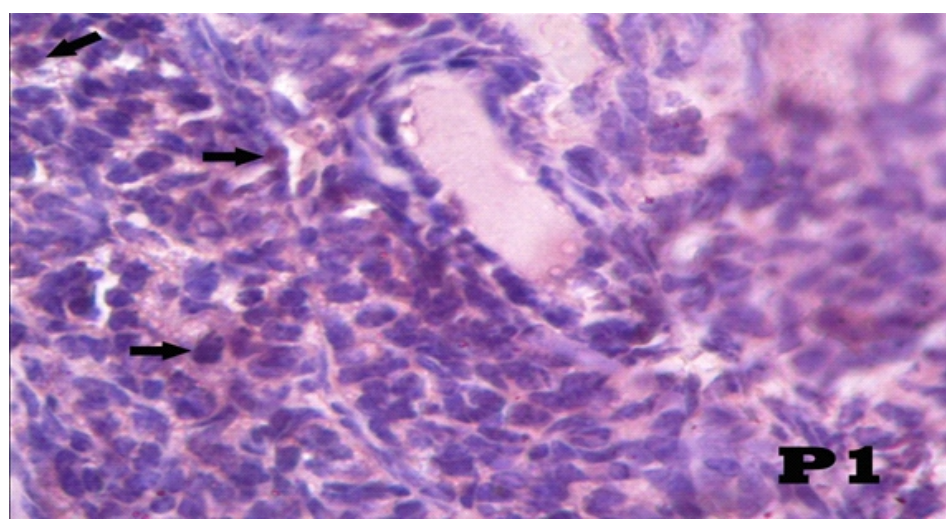

Figure1. The expressions of caspase 3 in the ovaries. Notes: The black arrow shows the expressions of caspase 3 marked by the brown intensity in the cell nucleus (HE coloring; Magnification 100x; Olympus ${ }^{\circledR}$ CX-41 Microscope).

The statistical test showed that the level of malondialdehyde (MDA) in K- was significantly different $(\mathrm{p}<0.05)$ from $\mathrm{K}+, \mathrm{P} 1, \mathrm{P} 2$ and P3. P2 and P3 were not significantly different $(p>0.05)$. The level of MDA was very high, which was 45.49 in the zearalenone exposure without mycotoxin binders addition (K-). The levels of MDA decreased gradually: 34.92; 27.72; and 23.89 in P1, P2, and P3 respectively, while in the positive control $(\mathrm{K}+)$ the level of MDA was the lowest, with the mean of 15.48 .

The statistical test on the quantities of corpus luteum in each treatment was significantly different $(\mathrm{p}<0.05)$; therefore, Duncan tests had to be conducted. The Duncan tests show that K- was significantly different $(\mathrm{p}<0.05)$ from $\mathrm{K}+, \mathrm{P} 1, \mathrm{P} 2$ and $\mathrm{P} 3$. The lowest number of corpus luteum (2.95), was gained in the zearalenone exposure without any addition of mycotoxin binders (K-). The quantities of corpus luteum increased gradually, 4.50; 5.43; dan 8.30 in P1, $\mathrm{P} 2$, and $\mathrm{P} 3$, while in the positive control $(\mathrm{K}+)$ the number of corpus luteum reached a mean of 9.55 . Figure 2 shows the quantities of corpus luteum.

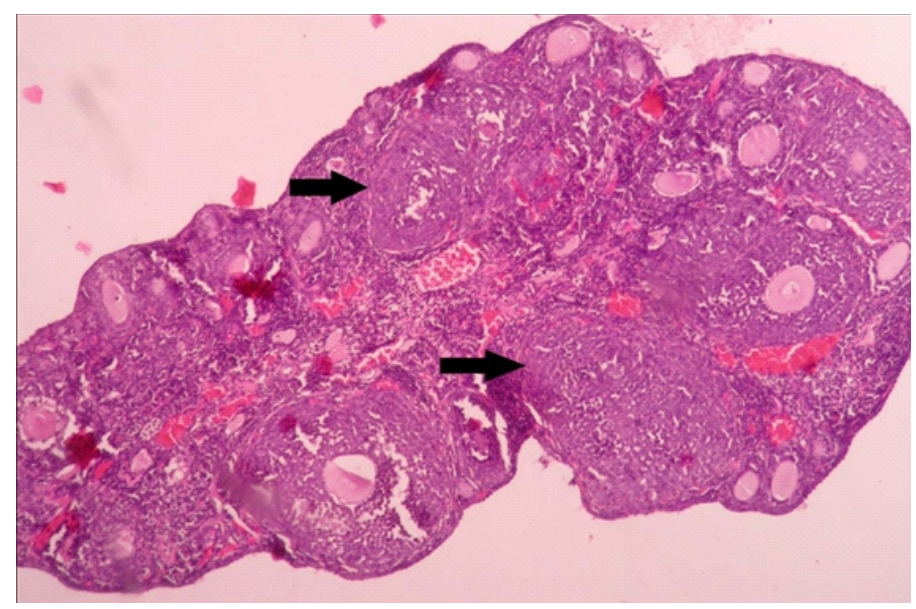

Picture 2. The quantities of corpus luteum. Note: The black arrow shows the corpus luteum during the observation (Imunohistochemical coloring; Magnification 100x; Olympus ${ }^{\circledR}$ CX-41 Microscope). 
Zearalenone is metabolized in the liver with an enzyme called hydroxysteroid dehydrogenase which is then changed into two isomeric metabolites, $\alpha$ Zearalenol and $\beta$ Zearalenol. Both metabolites are distributed through blood vessels to targeted organs and can cause toxicity (Schoevers et al., 2012).

The cytotoxicity effects of zearalenone can also cause an abnormal estrus cycle in female pigs (Bridges et al., 2008). Zearalenone can also cause pathological changes in the ovaries (Opletal and Šimerda, 2006; Schoevers et al., 2012). Zearalenone in pigs can cause granulose cell apoptosis changes (Obremski et al., 2003). The derivatives of zearalenone, $\alpha$-dan $\beta$-zearalenols, obstruct the progesterone synthesis in pig ovaries and reduce the number of corpus luteum in the pregnant pigs (Tiemann et al., 2003).

Molecularly, zearalenone toxic effects can trigger oxidative stress and induce intrinsic line apoptosis in mitochondria. The apoptosis process, especially in livers and reproductive organs, produces excessive ROS and is connected with the mitochondrial line apoptosis (Albano, 2008; Holme et al., 2007). Research data from Bouaziz et al., (2008) showed that ROS was produced from zearalenone exposure, and mitochondrial changes occurred due to the increase in the ROS level, which showed that zearalenone could induce oxidative stress, causing apoptosis.

DNA damages caused by zearalenone's mycotoxin can trigger p53 activation, which then triggers proapoptosis protein translocation such as bax in the mitochondrial membranes (Bouaziz et al., 2008). The adhesions of proapoptosis protein in the membranes will cause mitochondrial permeability, causing PT pore to open which can trigger extracellular $\mathrm{Ca}^{2+}$ to become intracellular, followed by the loss of electron transfer ability and ATP synthesis
(Kilianska and Miśkiewicz 2003, Maresca and Fantini 2010). The influx of $\mathrm{Ca}^{2+}$ inside the mitochondria will release c cytochromes into the cytosols. Oxidative stress will cause c cytochromes to leave the mitochondria and bind to Apoptotic Protease Activating Factor 1 (Apaf 1) to produce apoptosome compounds. Apoptosome compounds will induce procaspase 9 to activate caspase 9 . Caspase 9 will then induce procaspase 3 to activate caspase 3 (Kumar et al., 2005).

Mycotoxin binders contain aluminosilicate active carbons (Avantaggiato et al., 2005) whose mechanism is to eliminate methyl groups in the zearalenone chemical structure and produce charcoal compounds (Doll et al., 2004).

\section{Conclusions}

The experiment concludes that mycotoxin binders causes the decrease in the caspase 3 expression and MDA level in the mouse ovaria due to zearalenone exposure. Mycotoxin binders are antagonistic to zearalenone, and thus cause no reduction in the quantity of corpus luteum due to zearalenone exposure.

\section{Acknowledgement}

We would like to acknowledge the full support of the research team for the experiment. Special thanks are directed to Dr. Abdul Samik, drh., M.Si., senior lecturer at the Faculty of Veterinary Medicine, Universitas Airlangga, for the research funding.

\section{References}

Abbes, S., Z. Ouanes, J.B. Salah-Abbes, Z. Houas, R. Oueslati, H. Bacha, O. Othman. (2006). The Protective Effect of Hydrated Sodium Calcium Aluminosilicate Against Haematological, Biochemical and Pathological Changes Induced by Zearalenone in Mice. Toxicology. 47:567-574. 
Albano, E. (2008). Oxidative Mechanisms in The Pathogenesis of Alcoholic Liver Disease. Mol.Asp. Med.29:9-16.

Avantaggiato, G., M. Solfrizzo, and A. Visconti. (2005). Recent advances on the use of adsorbent materials for detoxification of Fusarium mycotoxins. Food Additives and Contaminants. 22:379-388.

Awoniyi C.A., D. Roberts, and D.N. Veeramachaneni. (1998). Reproductive Sequelae in Female Rats After in Utero and Neonatal Exposure to The Phytoestrogen Genistein. Fertility and Sterility. 70:440-447.

Bouaziz, C., O.S. el Dein, E. el Golli, S. Abid-Essefi, C. Brenner, C. Lemaire and H. Bacha. (2008). Different Apoptotic Pathways Induced by Zearalenone, T-2 Toxin and Ochratoxin A in Human Hepatoma Cells. J.Toxicology 254:19-28.

Bridges, A., R. Lemenager, B. Richert and M. Schutz. (2008). Animal Sciences: Zearalenone Concerns in Reproducing Livestock. Department of Animal Sciences. Purdue $\begin{array}{llllllllllllllllll} & n & i & v & e & r & s & i & t & y & \text {. }\end{array}$ https://www.extension.purdue.edu/extmedia/ AS/AS-598-W.pdf[12 June, 2015

Döll, S., S. Dänicke, H. Valenta, and G. Flachowsky. (2004). In vitro studies on the evaluation of mycotoxin detoxifying agents for their efficacy on deoxynivalenol and zearalenone. Arch. Anim. Nutr. 58:311-324.

Gajecka, M. (2012). The effect of low-dose experimental zearalenone intoxication on the immunoexpression of estrogen receptors in the ovaries of pre-pubertal bitches. Department of Veterinary Prevention and Feed Hygiene. Faculty of Veterinary Medicine, University of Warmia and Mazury in Olstyn, Oczapowskiego. Poland. J Vet. Sci. 15(4):685-691.

Holme, J.A., M. Gorria, M. Arlt Volker, S. Øvrebø, A. Solhaug, X. Tekpli, E. Landvik Nina, L. Huc, O. Fardel and D. Lagadic-Gossmann. (2007). Different Mechanisms Involved in Apoptosis Following Exposure to Benzo[a]pyrene in F258 and Hepalc1c7 Cells. Chem. Biol. Interact. 167:41-55.

Kiliańska, Z.M. and A. Miśkiewicz. (2003). Caspases of The Vertebrates - Their Role in Apoptosis. Postęy Biologii Komórki. 30: 129-152.
Kumar, V., RS. Cotran, and S. Robins. (2005). Basic Pathology $7^{\text {th }}$ Ed, Saunders Philadelphia. Indonesian edition: Penerbit Buku Kedokteran EGC. Jakarta, pp. 3-33.

Laurence, DR. and AL. Bacharach. (1993). Evaluation of Drug Activities and Pharmacometrics, Academic Press London and New York 1: pp. 160161.

Maresca, M., and J. Fantini. (2010). Some foodassociated mycotoxins as potential risk factors in humans predisposed to chronic intestinal inflammatory diseases. Toxicon. 56: 282-294.

Obremski, K., M. Gajecki, W. Zwierzchowski, L. Zielonka, I. Otrocka-Domagala, T. Rotkiewicz, A. Mikolajczyk, M. Gajecka and M. Polak. (2003). Influence of Zearalenone on Reproductive System Cell Proliferation in Gilts. Polish Journal of Veterinary Sciences. 6:239-245.

Opletal, L. and B. Šimerda. (2006). Flavanoids in A nimal Nutrition. http://www.vuzv.cz/old/vyziva/ studie29.pdf. [8 March, 2015]

Schoevers E.J., R.R Santos, B. Colenbrander, J. FinkGremmels and B.A. Roelen. (2012). Transgenerational Toxicity of Zearalenone in Pigs. J Reprod Toxicol.34(1):110-119.

Schollenberger, M., W. Drochner, H.M Müller. (2007). Fusarium Toxins of The Scirpentriol Subgroup: A Review. Mycopathologia 164 (3):101-118.

Sinuhaji, I., B. Siregar, dan Lisnawati. (2013). Ekspresi p16 ${ }^{\text {IKKA }}$ pada Karsinoma Serviks Usia Muda. Departemen Patologi Anatomik. Fakultas Kedokteran Universitas Indonesia. Jakarta. $J$ Indon Med Assoc 63:1.

Tiemann, U., T. Viergutz, L. Jonas, and F. Schneider. (2003). Influence of the mycotoxins - and zearalenol and deoxynivalenol on the cell cycle of cultured porcine endometrial cells. J Reprod. Toxicol. 17(2):209-218 